\title{
On Chinese Ancient Architectural Style
}

\author{
Yanqi Liu \\ Art and Design Department \\ North China University of Water Resources and Electric Power \\ Zhengzhou, Henan, China 450000
}

\begin{abstract}
This paper introduces the ancient architectural styles created in the long history of China. It briefly describes the political, social and cultural backgrounds in the period of feudal society and related features of our feudal monarchy oriented ancient architecture system penetrated with the ethical ideas and rites and music of Chinese people.
\end{abstract}

Keywords-feudal society; ancient architecture; style; Confucianism

\section{INTRODUCTION}

China has a long history of about 5000 years. Over more than 2000 years of feudal society, feudal thought has deeply rooted in the culture and livelihood of the nation. As a production of the age, ancient Architectural style was also deeply affected by the society.

The feudal age lasted for more than 2000 years lays a good foundation for the prosperous and stability of Chinese feudal society. Chinese traditional architecture was also a production under such a social and political environment, reached its climax and became a glorious branch in the architectural history of the world.

\section{FORMATION OF ANCIENT ARCHITECTURAL STYLE}

The high-strength ruling environment also unifies the boundary of architectural art. Except people of imperial lineage and nobles, the dwellings of general ministers and ordinary citizens are generally facing toward the south, with the meaning to worship the emperor. Except imperial city and temples, other buildings are generally built up with blue bricks and grey tiles, in mode of quadrangle courtyard arranged like a army array, so as to show an insignificant and humble posture in front of the imperial city. In the dwelling, there is high and thick fence and closed courtyard. Only the imitated natural garden or delicate courtyard becomes the unique path to the open air. In the courtyard, you can see everywhere the engraved characters, horizontal inscribed board or inscription showing Buddhism and Confucianism such as “超凡脱俗(to be outstanding)”, “精忠不渝 (to be loyal)" and “无欲无求 (to be desire-less)", as well as tile carvings, color paintings and decorations derived from story of Confucianism and Buddhism figures and mascots covered on beams, walls and ridges. Doors and windows, ceilings, sunk panel, partition wall, cover and furniture in room are all engraved with sculpture and decorative design about Buddhism and Confucianism. The superlative belief to
Buddhism and Confucianism indicates the householder's loyalty to the dynasty. The self-examination, silent but longfor-freedom characters of Chinese people are incorporated into the architecture under the great imperial power. The emotion of poet and the evasive part in architecture faintly implies that people takes things as they come and is long for the dreamland.

The unified urban space with highlights in center is the production under the powerful feudal ruling. The layout of Beijing City is in symmetry, with Yongdingmen Zhengyangmen - the Forbidden City as the central axis. The imperial city is located in the north end of the central axis and is the key point of the whole city. The imperial city is surrounded with 37 lanes. The end Hutong in each lane is vertical to the trunk road, with a unified and orderly layout and easy to control.

Downtown is a relatively bustling place in a city. Partial downtowns are built beyond large temples. In downtown, there are generally hotels and wine shops, with suitable street spaces. In comparison with dwellings, there are relatively various street spaces and architectural boundaries. However, the form and materials of such buildings is not that different from ordinary dwellings. The building is mainly in grey color, serving as a foil to the imperial city.

"Complex" is the soul of Chinese architectural art. Complex layout is the advantage of timberwork art in ancient Chinese buildings. The beauty of Chinese architecture is right hidden inside the complex and is shown in a global view. The complex shows more in inner beauty than in appearance. In terms of the beauty of a single building, Western architecture pays more attention to the creation and variety in appearance, while Chinese architecture shows more in the harmony, tranquility and lasting appeal given by the relation between group and part shown by combination of body, face, line and point.

\section{PALACE BUILDINGS IN CHINA}

During the more than 2000 years of feudal society after the First Emperor of Qin unified the central China and established the first feudal dynasty with centralization of authority in China, the dictatorship system of feudal dynasty was increasingly perfected and consolidated. Imperial power became the supreme power of the country. Represented by the existing Forbidden City in Beijing, palace is the most magnificent architectural type enjoying the most worship and with the highest achievement. The Forbidden City is located 
in the center of the capital, with a series of longitudinal spaces distributed along the central axis (three audience halls in the front for holding court, three grand palaces in the rear for resting and the imperial garden). Tian'anmen square and Meridian Gate square are distributed in the front of the layout, Jingshan Mountain is in the rear and palace courtyards are distributed symmetrically in two sides of the central axis. The superb architectural shape, noble color processing, layer upon layer of courtyards with different sizes and in different direction as well as the gorgeously engraved architectural decoration all convincingly render the imperial power for the whole country, showing a deterrent effect on people. Buddhism and Confucianism were also given a prominent standing as they are inseparably interconnected with and support imperial power. The gorgeous, unified and distinctive ancient architecture was derived from the prosperous and strong feudal society with distinctive grading in China.

The ruling thought of Confucianism also posed a deep influence on Chinese ancient building. Its concept of rite and music takes blood relationship as the link, treats filial piety and fraternal duty as the foundation of rite and music and thinks that "They are few who, being filial and fraternal, are fond of offending against their superiors". Thereby, in addition to give direct affirmation on the principle between monarch and his subjects, Confucianism also had its theory rooted into each family ties, strengthening the order of superiors and interiors between father and son, the older and younger brothers, husband and wife, man and women as well as the older and younger. The typical layout of quadrangle courtyard in Chinese dwelling reveals the influence of Confucianism posed on Chinese dwelling. A quadrangle courtyard is generally divided into the front courtyard and the rear courtyard. The front courtyard is also called the outer courtyard for providing servants with accommodation and setting up kitchen and guest room. The rear courtyard is also called the inner courtyard. The central room is located in the central axis in the noblest position and with the noblest scale. In large dwelling, it is available to have several courtyards extended in the rear of the layout along the central axis and also available to have several courtyards connected right and left. People living in those courtyards are distinct in superiors and inferiors, close and distant, up and down as well as older and younger, depending on the relation between the courtyard and the central room. The whole dwelling shows a strict patriarchal clan system. According to archaeological materials, such dwelling layout in compliance with the concept of rite and music hadn't been subjected to any change in principle and in general, from Han dynasty at the latest to Qing dynasty. Meanwhile, the layouts of dwelling and palace are also the same in principle. The courtyard of Western Zhou Dynasty, excavated in Fengchu Village, Qishan County, Shaanxi Province in recent years, is the site of a palace. Unexpectedly, its shape and structure are very similar to the quadrangle courtyard in Qing dynasty. In addition, government office, ancestral temple of a ruling house, ancestral hall, guild hall and tomb also show a strong concept of rite and music. Even in Buddhist and Taoist temples, there is also an atmosphere of rite and music, which is quite different from western religious building. In the long lasting patriarchal society, Chinese architecture got the highest achievement in palace and capital planning which highlights the concept of the supreme imperial power and the strict sense of hierarchy and reflects the political ethics that ancient China takes the dominant position.

\section{RELIGIOUS BUILDINGS IN CHINA}

In ancient China, religious authority was always inferior to monarchical power. Therefore, Chinese religious architecture is in completely different pattern. With limited science level, the ancient people are inevitably to believe ghosts, gods and soul. However in China, Confucianism caring about politics and paying attention to human beings is clear about the issue of ghosts and gods. Although Confucius proposed the worship to ancestor as derived from the primitive society, he tried the best to reduce religious awareness from the worship and especially had the worship led to the human relations containing feudal order of importance or seniority on the basis of genetic connection.

The sober rationality of Confucianism has a deep influence on people especially on the governor and intellectual. Emperors in past dynasties that made difference all adopted the policy to limit religion while using and tolerating religion. The thought of karma and bringing trouble to oneself in Buddhism and the thought of passive inaction and taking things as they come in Taoism both can be used by the governor. Even the emperor would participate in some activities about Buddhist and Taoist to show his special favor. In art style, religious buildings in China had never been caught in the incitation of theology nor adopted ecstasy beyond human nature. In a word, sober rationality of human being is not lost even in religious architecture and is particularly paid more attention by Confucianism. Thereby, Chinese traditional architecture including religious architecture has a characteristic of rationality.

\section{CONCLUSION}

Abiding by traditional thinking, Chinese ancient architecture takes steps on the road of increasing perfectness and stable development. Over more than 2000 years, architecture has not that large change in basic type and always uses timber framework, thick and large sloping tile roof, layer upon layer of corbel bracket and raised truss. Architectural type reached its climax during the flourishing age of Tang and Song dynasties and was propagated to North Korea and Japan, taking the leading position in architectural field of the world. In general, Chinese architecture pays more attention to spirit and artistic conception in inner temperament. It abides by the aesthetic habits to be amiable, moderate, profound and implied and demonstrates the pursuing of Chinese national personality for aesthetics.

\section{REFERENCE}

[1] Wang Mingxian, "The spirit of Chinese ancient architectural aesthetics." Architecture of the times. 1992.18-21 